\title{
Inheritance of Quantitative Expression of Erythrocyte Glucose-6-Phosphate Dehydrogenase Activity in the Negro-A Twin Study
}

\author{
George J. Brewer, ${ }^{1,2}$ John C. Gall, ${ }^{1,2}$ Merton Honeyman, ${ }^{3}$ Henry Gershowitz, ${ }^{2}$ \\ Donald C. Shreffler, ${ }^{2}$ Raymond J. Dern, ${ }^{4}$ and Curtis Hames ${ }^{5}$
}

Received 20 Nov. 66

Studies have been conducted on eight sets of monozygous and nine sets of dizygous female Negro twins, both members of whom were heterozygous for G-6-PD deficiency. Twins were studied both by assay of erythrocytic G-6-PD activity and by the methemoglobin elution test (MET). The MET is a procedure which identifies histochemically cells with appreciable G-6-PD activity and permits accurate determination of the percentage of such cells in heterozygotes. Monozygous twins showed significantly less "within-pair" variation than dizygous twins with both the MET and G-6-PD assay.

Concerning the significantly greater agreement in $M E T$ results in monozygous twins than dizygous twins, our present working hypothesis is that $X$-chromosomal inactivation in the Negro female is genetically controlled, rather than random. However, certain alternate hypotheses allowing for random $X$-inactivation have not been excluded; these include somatic cell selection after random $X$-inactivation, and cell exchange between identical twins in utero. Studies in nontwin related heterozygotes now underway should help differentiate among these various possibilities.

In addition to the studies on 17 pairs of female twins heterozygous for G-6-PD deficiency, 26 pairs of nondeficient female Negro twins have been studied by G-6-PD assay. Within-pair variation in monozygous twins was significantly less than within-pair variation in dizygous twins in all cases. The genetic influences detected with the G-6-PD assay in the female twins could theoretically be due to nonrandom X-inactivation, to genetically determined quantitative differences in enzyme activity (e.g., isoalleles),

Supported by USPHS research grants AM-09381, HE-17544, AM-09919, and HE-03341, by USPHS Career Development Award 1-K3-AM-7959 (Dr. Brewer) and by U.S.A.E.C. Contract (11-1)-1552.

${ }^{1}$ Department of Medicine (Simpson Memorial Institute) University of Michigan Medical School, Ann Arbor.

${ }^{2}$ Department of Human Genetics, University of Michigan Medical School, Ann Arbor.

${ }^{3}$ Connecticut State Department of Health, Hartford.

${ }^{4}$ Department of Medicine, Stritch School of Medicine, Loyola University, and the Hektoen Institute of the Cook County Hospital, Chicago.

${ }^{5}$ Hames Clinic, Claxton, Georgia. 
or to both. By appropriate calculations, based on the MET results, we have factored out the effects of $X$-inactivation on overall enzyme activity in the heterozygous deficient twins. After removal of the effect of $X$-inactivation, monozygous twins heterozygous for enzyme deficiency continue to show significantly less within-pair variation than dizygous twins. This finding indicates significant genetic influences on quantitative G-6-PD activity other than $X$-inactivation and other than the deficiency allele. This conclusion has been strengthened by studies on male twins where $X$-inactivation is not present.

\section{INTRODUCTION}

Interest in X-linked genes has mounted steadily subsequent to developments concerning the sex chromatin body (Barr and Bertram, 1949; Ohno et al., 1959) and the presentation of the X-chromosome inactivation hypothesis by Lyon (1961) and by Beutler et al. (1962). In general, the X-inactivation hypothesis holds that one of the $\mathrm{X}$-chromosomes in each somatic cell of the female is genetically inactivated at an early stage in embryogenesis, that the decision as to whether the paternally or maternally derived X-chromosome is inactivated in a given cell is random, and that after the $\mathrm{X}$-chromosome inactivation the daughter cells of any cell have the same inactive $\mathrm{X}$-chromosome as the parent cell. Cytologically, the inactive $\mathrm{X}$-chromosome is thought to be represented by the sex chromatin body. The hypothesis explains dosage compensation of genes located on the X-chromosome, i.e., similar phenotypic expression in individuals having only one X-chromosome (males) and in individuals having two X-chromosomes (females). The hypothesis is considered to be applicable to all mammalian females, including the human. The most extensive work in women has been done with $\mathrm{X}$-linked mutant genes determining either deficiency (Carson et al., 1956) or electrophoretic variation (Porter et al., 1961; Boyer et al., 1962; Kirkman and Hendrickson, 1963) in glucose-6-phosphate dehydrogenase (Beutler et al., 1962 and 1964; Davidson et al., 1963).

The present work has been directed toward: (1) Testing the postulated randomness of X-chromosomal inactivation. The experimental method has involved the use of the G-6-PD deficiency gene as a marker, and a histochemical procedure (methemoglobin elution test) for identifying cells with G-6-PD activity. This portion of the study has been conducted in Negro female twins, heterozygous for G-6-PD deficiency. (2) The evaluation of inheritance of quantitative expression of G-6-PD activity in the Negro population, aside from X-chromosomal inactivation. This study has utilized quantitative assay of G-6-PD activity as the experimental method. It has been conducted in (a) nondeficient Negro female twins, (b) nondeficient Negro male twins, and (c) Negro female twins heterozygous for G-6-PD deficiency (by utilizing a correction to factor out the variable influence of $\mathrm{X}$-chromosomal inactivation).

\section{METHODS}

\section{Subjects}

The subjects were 98 sets of female Negro twins and 31 sets of male Negro twins. In addition, some members of the families of the female twins were studied. The relatives 
studied varied from family to family according to availability, but efforts were made to study at least the parents, particularly when both twins were heterozygous for G-6-PD deficiency. Eighty-three of the female twin sets (and all of the male twin sets) were obtained from the twin registry of the Connecticut State Department of Health. Nine sets of female twins were obtained from Evans County, Georgia, where they had previously participated in a study of serum cholesterol. Six sets of female twins were obtained from Chicago, Illinois. The G-6-PD phenotype of all twins was unknown prior to this study.

\section{Zygosity}

Four methods of evaluating zygosity were carried out on most twins. The first consisted of extensive blood typing and typing for serum and red cell biochemical markers. These were the ABO, MNS, $\mathrm{P}, \mathrm{Rh}, \mathrm{K}, \mathrm{Fy}^{\mathrm{a}}$, $\mathrm{Jk}^{\mathrm{a}}, \mathrm{Js}^{\mathrm{a}}, \mathrm{Le}^{\mathrm{a}}$, and $\mathrm{Le}^{\mathrm{b}}$ blood groups, the Tf, Hp, and Gc serum protein types, in most cases the G-6-PD, 6-phosphogluconate dehydrogenase, acid phosphatase, and phosphoglucomutase red cell enzyme types, and hemoglobin types. The second consisted of asking the family (usually the mother) a series of questions designed to reveal whether they (or she) thought the twins were identical or nonidentical, and recording the answers. The third consisted of the visual impression of the fieldworker (GJB or JCG) as to zygosity, when the twins were seen at the same time. The fourth consisted of a colored slide of the twins taken by the fieldworker at the time of the study, which was subsequently reviewed and a zygosity impression recorded. Special studies, including reciprocal skin grafting, ${ }^{6}$ were carried out on one set of twins.

\section{Evaluation of G-6-PD Deficiency and of Quantitative Expression of G-6-PD Deficiency in Heterozygotes}

All blood samples were collected in heparin and acid-citrate-dextrose as anticoagulants and kept constantly iced or refrigerated $(4.0 \mathrm{C})$ until use. After collection in the field they were taken to an airport and sent by air express to our laboratories at the University of Michigan, where all laboratory procedures were carried out. The methemoglobin reduction test (Brewer et al., 1960) and the methemoglobin elution test (MET) (Gall et al., 1965), were performed by methods previously described. In essence, the MET is a histochemical cell-staining procedure-cells with appreciable G-6-PD activity staining, and those with little activity not staining. Assay of the G-6-PD activity of hemolysates was performed by the method of Zinkham and Lenhard (1959).

During the first two-thirds of the study, the samples were screened for G-6-PD deficiency by the methemoglobin reduction test. This procedure is approximately $80 \%$ effective in detecting heterozygotes and is as efficient as quantitative enzyme assay in this regard. When either twin or either parent was positive for G-6-PD deficiency on screening, the G-6-PD activity of the erythrocytes of the twins was

${ }^{6}$ Carried out through the courtesy of Dr. Irving Feller, Department of Surgery, University of Michigan. 
determined, and a repeat blood sample taken for the MET. We were unable to obtain a repeat blood sample for the MET on one set of identical twins heterozygous for G-6-PD deficiency. During the last one-third of the study, all of the female twins were screened by both the methemoglobin reduction test and the MET; the latter appears to approach $100 \%$ efficiency in heterozygote detection (Gall et al., 1965).

\section{RESULTS}

In seventeen sets of female twins it was ascertained that both twins were heterozygous for G-6-PD deficiency. All eight sets of twins in whom the visual impression, family impression; and photographic evidence indicated dizygosity were discordant with respect to at least two blood group or biochemical markers. On the other hand, all nine sets of twins in whom the visual impression, family impression, and photographic evidence indicated monozygosity were completely concordant in all blood type and biochemical marker systems tested (13-18 markers).

Table I shows the G-6-PD assay and MET results in these 17 sets of twins. One set of identical twins (set 17) was not available for testing with the MET. Comparison of the MET results (columns 1 and 2) in the two types of twins reveals a much smaller intrapair difference in identical twins than in nonidentical twins (column 2). In six of the eight identical sets on whom this test was conducted, agreement between twins was within the limits of the experimental error of the method. In the other two identical sets (sets 13 and 15), within-pair differences were considerably higher. In nonidentical twins, within-pair differences ranged from 7.1 to $39 \%$, and averaged $18.5 \%$.

Comparison of the "raw" G-6-PD activity data in the two types of twins also demonstrates a considerably closer agreement between identical twins than nonidentical twins (Table I, columns 3 and 4). Mean within-pair differences in identical twins (29) was about one-third that of nonidentical sets (82). It is possible, by applying the results of the MET and by making certain assumptions, to "correct" the G-6-PD activity data so that they reflect only the activity of the genetically unaffected (nondeficient) subpopulation of red cells. (For calculations and assumptions see Appendix.) The activity of the nondeficient cells is shown in Table I, column 5 .

A further computation (see Appendix) yields a number we have termed the "relative activity," which is a reflection of the amount of activity relative to the number of genetically unaffected (nondeficient) cells. This computation is designed to yield a value which is comparable with the activity of normal (nondeficient) individuals. For comparative purposes, mean G-6-PD activity of erythrocytes from nondeficient Negroes in our laboratory is $287 \pm 38$ (one S.D.) $\mu$ moles of triphosphopyridine nucleotide reduced per gram of hemoglobin per hour, at 23C). The relative activities and the associated intrapair differences are shown in Table I, columns 6 and 7. The mean intrapair difference in relative activity of monozygous twins (45.6) is considerably smaller than that of dizygous twins (122.5).

Statistical evaluation of the heterozygous female data by analysis of variance is shown in Table II. In heterozygous deficient twins, within-pair mean squares are significantly smaller for both the MET and G-6-PD assay (both raw value and relative activity) in identical twins compared to nonidentical twins. 
Table I. Results of G-6-PD Assay and the MET in the 17 Sets of Negro Female twins Heterozygous for G-6-PD Deficiency

\begin{tabular}{|c|c|c|c|c|c|c|c|}
\hline \multirow[b]{2}{*}{ Set No. } & \multicolumn{2}{|c|}{ MET } & \multicolumn{3}{|c|}{ G-6-PD Assaya } & \multirow[b]{2}{*}{$\begin{array}{c}\text { Relative } \\
\text { activity } \\
\text { (6) }\end{array}$} & \multirow{2}{*}{$\begin{array}{c}\text { Intrapair } \\
\text { difference } \\
(7)\end{array}$} \\
\hline & $\begin{array}{l}\% \text { Stained } \\
\text { cells } \\
(1)\end{array}$ & $\begin{array}{l}\text { Intrapair } \\
\text { difference } \\
\text { (2) }\end{array}$ & $\begin{array}{l}\text { Raw } \\
\text { value } \\
(3)\end{array}$ & $\begin{array}{l}\text { Intrapair } \\
\text { difference } \\
\text { (4) }\end{array}$ & $\begin{array}{l}\text { Activity of non- } \\
\text { deficient cells } \\
\text { (5) }\end{array}$ & & \\
\hline \multicolumn{8}{|c|}{ Dizygous TwINs } \\
\hline \multirow[t]{2}{*}{1} & 45.4 & & 135 & & 117 & 334 & \\
\hline & 59.9 & 14.5 & 176 & 31 & 163 & 312 & 22 \\
\hline \multirow[t]{2}{*}{2} & 62.5 & & 224 & & 211 & 382 & \\
\hline & 37.6 & 24.9 & 105 & 119 & 84 & 328 & 54 \\
\hline \multirow[t]{2}{*}{3} & 70.1 & & 202 & & 192 & 298 & \\
\hline & 51.6 & 18.5 & 128 & 74 & 112 & 264 & 34 \\
\hline \multirow[t]{2}{*}{4} & 55.7 & & 200 & & 185 & 392 & \\
\hline & 73.3 & 17.6 & 283 & 83 & 274 & 402 & 10 \\
\hline \multirow[t]{2}{*}{5} & 19.6 & & 55 & & 28 & 656 & \\
\hline & 36.2 & 16.6 & 98 & 43 & 77 & 320 & 336 \\
\hline \multirow[t]{2}{*}{6} & 84.8 & & 193 & & 188 & 229 & \\
\hline & 75.0 & 9.8 & 234 & 41 & 226 & 322 & 93 \\
\hline \multirow[t]{2}{*}{7} & 47.4 & & 178 & & 160 & 429 & \\
\hline & 54.5 & 7.1 & 112 & 66 & 97 & 211 & 218 \\
\hline \multirow[t]{2}{*}{8} & 74.0 & & 392 & & 383 & 556 & \\
\hline & 35.0 & 39.0 & 196 & 196 & 174 & 771 & 215 \\
\hline \multicolumn{6}{|c|}{$\begin{array}{ll}\text { Mean } \ldots \ldots \ldots \ldots \ldots \ldots . . . . . .18 .5 & 181.9 \\
\text { Ratio of mean intrapair difference to } & \end{array}$} & 387.9 & 122.5 \\
\hline & \multicolumn{2}{|c|}{0.316} \\
\hline
\end{tabular}

\begin{tabular}{|c|c|c|c|c|c|c|c|}
\hline & & & MoNC & Us TwINs & & & \\
\hline 9 & 74.9 & & 253 & & 245 & 349 & \\
\hline & 74.7 & 0.2 & 204 & 49 & 196 & 280 & 69 \\
\hline 10 & 65.8 & & 216 & & 205 & 345 & \\
\hline & 64.8 & 1.0 & 208 & 8 & 196 & 338 & 7 \\
\hline 11 & 56.8 & & 151 & & 137 & 281 & \\
\hline & 58.3 & 1.5 & 177 & 26 & 163 & 324 & 43 \\
\hline 12 & 69.0 & & 175 & & 165 & 261 & \\
\hline & 68.1 & 0.9 & 154 & 21 & 143 & 231 & 30 \\
\hline 13 & 57.3 & & 129 & & 115 & 233 & \\
\hline & 68.2 & 10.9 & 158 & 29 & 147 & 237 & 4 \\
\hline 14 & 71.8 & & 371 & & 362 & 544 & \\
\hline & 69.5 & 2.3 & 314 & 57 & 304 & 477 & 67 \\
\hline 15 & 62.8 & & 228 & & 216 & 387 & \\
\hline & 45.6 & 17.2 & 188 & 40 & 170 & 483 & 96 \\
\hline 16 & 74.8 & & 205 & & 197 & 281 & \\
\hline & 74.1 & 0.7 & 237 & 32 & 228 & 330 & 49 \\
\hline 17 & & & 190 & & & & \\
\hline & & & 189 & 1 & & & \\
\hline Mean . & $\ldots \ldots$ & 4.2 & 210.5 & 29 & & 336.3 & 45.6 \\
\hline $\begin{array}{l}\text { Ratio o } \\
\text { mean }\end{array}$ & $\begin{array}{l}\text { in int } \\
\text { e....... }\end{array}$ & difference to & ....... & & & & \\
\hline
\end{tabular}

${ }^{a}$ Expressed as $\mu$ moles TPN reduced per gram of hemoglobin per hour. 
Table II. Statistical Evaluation by Analysis of Variance of the MET and G-6-PD Assay in Negro Female Twins Heterozygous for G-6-PD Deficiency

\begin{tabular}{|c|c|c|c|c|}
\hline & $\mathrm{MZ}^{a}$ & $\mathrm{DZ}^{b}$ & $F$ ratio & $P$ \\
\hline \multicolumn{5}{|c|}{ MET } \\
\hline $\begin{array}{l}\text { Between-pair mean squares....... } \\
\text { Degrees of freedom ................ }\end{array}$ & $\begin{array}{c}113.9 \\
7\end{array}$ & $\begin{array}{c}435.8 \\
7\end{array}$ & & \\
\hline $\begin{array}{l}\text { Within-pair mean squares ....... } \\
\text { Degrees of freedom ................ }\end{array}$ & $\begin{array}{c}26.5 \\
8\end{array}$ & $\begin{array}{c}214.1 \\
8\end{array}$ & 8.08 & $<0.01$ \\
\hline$r_{I}^{c}$ & $\begin{array}{r}0.62 \\
<0.05\end{array}$ & $\begin{array}{c}0.34 \\
\mathrm{NS}^{d}\end{array}$ & & \\
\hline \multicolumn{5}{|c|}{ G-6-PD AsSAY-RAW VALUE } \\
\hline $\begin{array}{l}\text { Between-pair mean squares....... } \\
\text { Degrees of freedom ...................... }\end{array}$ & $\begin{array}{c}6756.5 \\
8\end{array}$ & $\begin{array}{c}8820.9 \\
7\end{array}$ & & \\
\hline $\begin{array}{l}\text { Within-pair mean squares } \\
\text { Degrees of freedom .......................... }\end{array}$ & $\begin{array}{c}572.1 \\
9\end{array}$ & $\begin{array}{c}4656.8 \\
8\end{array}$ & 8.14 & $<0.01$ \\
\hline$r_{I} \ldots \ldots \ldots$ & $\begin{array}{r}0.84 \\
<0.01 \\
\end{array}$ & $\begin{array}{l}0.31 \\
\mathrm{NS}\end{array}$ & & \\
\hline \multicolumn{5}{|c|}{ G-6-PD Assay-ReLative Activity } \\
\hline $\begin{array}{l}\text { Between-pair mean squares....... } \\
\text { Degrees of freedom ................ }\end{array}$ & $\begin{array}{c}17,456.13 \\
7\end{array}$ & $\begin{array}{c}34,292.67 \\
7\end{array}$ & & \\
\hline $\begin{array}{l}\text { Within-pair mean squares ....... } \\
\text { Degrees of freedom ................ }\end{array}$ & $\begin{array}{c}1,480.00 \\
8\end{array}$ & $\begin{array}{c}13,746.87 \\
8\end{array}$ & 9.28 & $<0.01$ \\
\hline$r_{P}$ & $\begin{array}{r}0.84 \\
<0.01\end{array}$ & $\begin{array}{l}0.42 \\
\mathrm{NS}\end{array}$ & & \\
\hline
\end{tabular}

${ }^{a} \mathrm{MZ}$ refers to monozygous.

${ }^{b} \mathrm{DZ}$ refers to dizygous.

${ }^{c} r_{I}$ refers to intraclass correlation.

dNS refers to nonsignificant.

The data obtained on activity of G-6-PD of erythrocytes in nondeficient twins (both female and male) are presented in Table III. The mean within-pair differences are less in identical twins than in nonidentical twins for both sexes. Statistical evaluation by analysis of variance is shown in Table IV. For both sexes within-pair mean squares are significantly smaller for monozygous nondeficient twins than for dizygous nondeficient twins.

\section{DISCUSSION}

Prior to discussing the results it seems pertinent to discuss the MET and G-6-PD assay in terms of the parameters measured by each. The MET is a measure of the proportion of cells with appreciable G-6-PD activity. Most cells of G-6-PD deficient hemizygotes and homozygotes are unstained, while those of normal individuals are stained. In Negroes, there is some artifact, or "noise," introduced in the detection of genetically determined ${ }^{7}$ enzyme-deficient cells by virtue of the fact that even in enzyme-deficient hemizygous males (G-6-PD deficiency is X-linked, Childs and 7 Throughout this discussion, the $\mathrm{X}$-chromosomal inactivation hypothesis is assumed to hold for this locus (G-6-PD) in this tissue (erythrytoces). 
Table III. Results of G-6-PD Assay in Nondeficient Female and Male Negro Twins

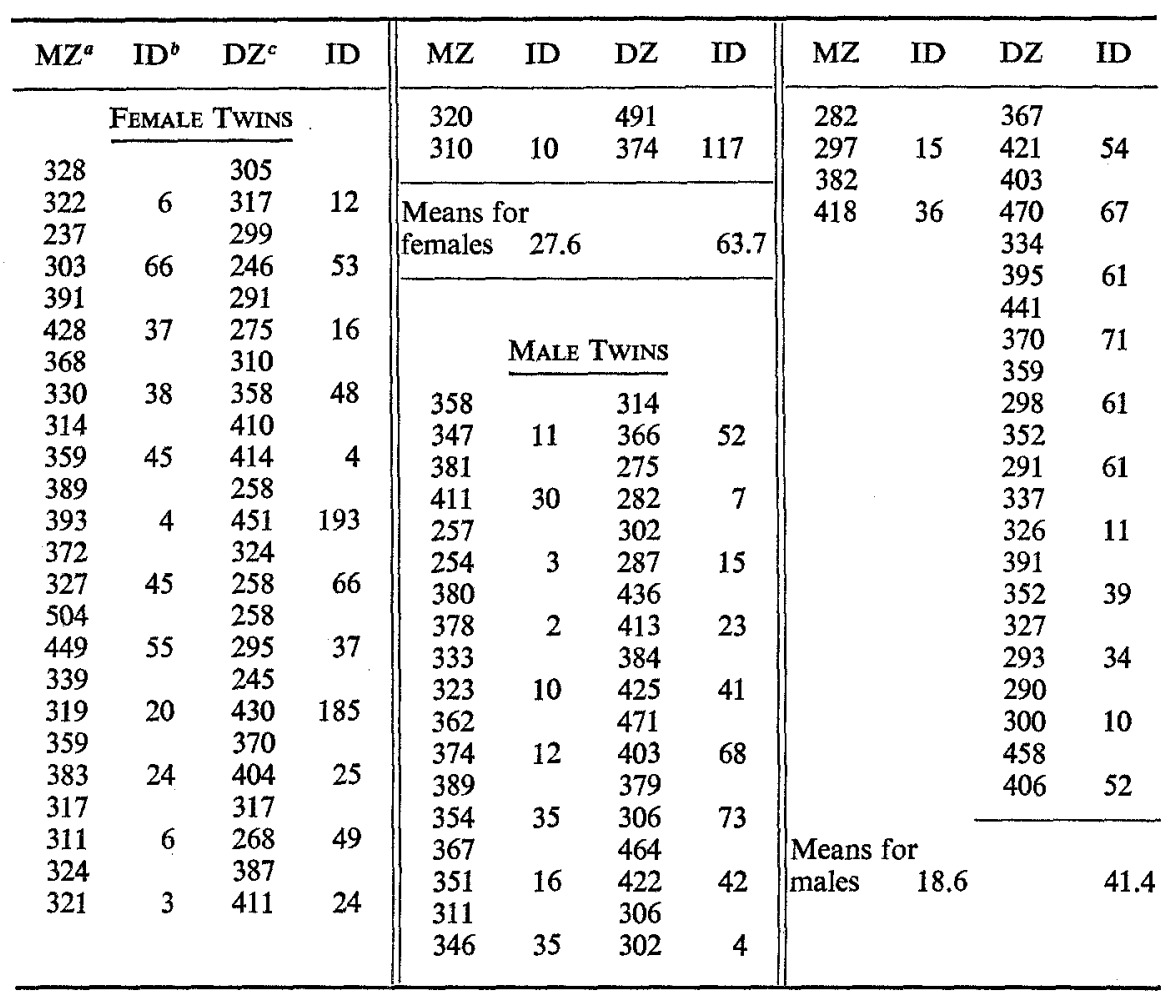

${ }^{a} \mathrm{MZ}$ refers to monozygous.

${ }^{b}$ ID refers to intrapair difference.

c $\mathrm{DZ}$ refers to dizygous.

Table VI. Statistical Evaluation of the G-6-PD Assay in Nondeficient Female and Male Negro Twins by Analysis of Variance

\begin{tabular}{|c|c|c|c|c|}
\hline & $\mathrm{MZ}^{a}$ & $\mathrm{D} Z^{b}$ & $F$ ratio & $P$ \\
\hline \multicolumn{5}{|c|}{ FEMALES } \\
\hline $\begin{array}{l}\text { Between-pair mean squares ........ } \\
\text { Degrees of freedom }\end{array}$ & $\begin{array}{c}5430 \overline{.94} \\
12\end{array}$ & $\begin{array}{c}6230.0 \\
12\end{array}$ & \multirow{3}{*}{6.48} & \multirow{3}{*}{$<0.01$} \\
\hline $\begin{array}{l}\text { Within-pair mean squares } \\
\text { Degrees of freedom } . . . . . . . . . . . . .\end{array}$ & $\begin{array}{l}592.96 \\
13\end{array}$ & $\begin{array}{c}3846.8 \\
13\end{array}$ & & \\
\hline$r_{I}^{c}$ & $\begin{array}{r}0.80 \\
<0.01 \\
\end{array}$ & $\begin{array}{r}0.24 \\
\mathrm{NS}^{d} \\
\end{array}$ & & \\
\hline \multicolumn{5}{|c|}{ MaLes } \\
\hline 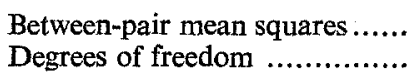 & $\begin{array}{c}3964 . \overline{25} \\
10\end{array}$ & $\begin{array}{c}5548.59 \\
19\end{array}$ & & \\
\hline 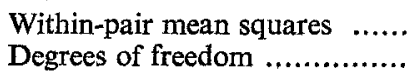 & $\begin{array}{c}250.23 \\
11\end{array}$ & $\begin{array}{c}1114.36 \\
20\end{array}$ & 4.45 & $<0.01$ \\
\hline$r_{Y}{ }_{P}$ & $\begin{array}{r}0.88 \\
<0.01\end{array}$ & $\begin{array}{r}0.66 \\
<0.01\end{array}$ & & \\
\hline
\end{tabular}

${ }^{a} \mathrm{MZ}$ refers to monozygous.

${ }^{c} \mathrm{DZ}$ refers to dizygous.
${ }^{b}$ ID refers to intrapair difference.

d NS refers to nonsignificant. 
Zinkham, 1959) about $16 \%$ of the cells stain, indicating significant G-6-PD activity. The activity of G-6-PD is known to be higher in young red cells of both normal and deficient individuals (Marks et al., 1958), and the stained red cells of deficient males in the MET are almost certainly the youngest $16 \%$ of cells. This view is supported by the results of centrifugation experiments, in which the stained red cells from deficient males can be partially concentrated in the top fraction of the column of centrifuged blood, and depleted in the bottom fraction (Gall and Brewer, 1966). In contrast, the mosaicism in the female heterozygote is probably mainly a result of $\mathrm{X}$-chromosomal inactivation, with a slight amount of superimposed "noise" from the youngest cells of the deficient subpopulation. This view is supported by centrifugation experiments performed on blood from heterozygotes; the stained cells can be concentrated only slightly in the top (and then only in heterozygotes with rather marked expression in whom the deficient subpopulation is large) and depleted only slightly in the bottom fraction (Gall and Brewer, 1966).

Thus, the MET as applied to heterozygotes, appears to reflect, for the most part, the mosaicism resulting from X-chromosomal inactivation. The amount of "noise" introduced by cell-age effects is small and can be estimated for a given heterozygote based on the known amount of "noise" in males and the size of the deficient subpopulation of cells in the heterozygote.

The G-6-PD assay, as applied to hemolysates of heterozygotes is also affected by X-chromosomal inactivation; but, in addition, the assay reflects the potential effects of several other variables. These include the possible existence of quantitative "normal" isoalleles (Davidson et al., 1964) at the G-6-PD locus and the possible modifying effects of the genetic and environmental background of the individual. By determining the percent of active cells in the MET, the G-6-PD activity can be corrected, and the activity relative to the number of genetically unaffected (nondeficient) cells obtained. This is called the relative activity, and it eliminates the variable effect of X-chromosomal inactivation. The remaining variability can then be attributed to the other factors listed above.

\section{Discussion of MET Results}

The data show unequivocally that monozygous Negro female twins heterozygous for G-6-PD deficiency have a significantly greater agreement than their dizygous counterparts in terms of the percent of cells staining in the elution test. Indeed, the agreement between elution test values in identical twins is extremely close in six of eight sets.

The usual interpretation of such findings in twins is that the character under study is inherited. The character under study with the MET is presumably X-chromosomal inactivation. If the assumption is made that $\mathrm{X}$-inactivation involves this locus, and that in general the staining or nonstaining of cells in the MET is a reflection of $\mathrm{X}$-inactivation, then one interpretation of the findings is that the proportion of paternally derived versus maternally derived X-chromosomes inactivated is inherited and not random as has been assumed. Further, the inheritance of this proportion in the six identical sets that agree so closely must be under very complete genetic control. If this explanation is accepted, it leaves unresolved the lack of very close agreement in 
the other two identical sets. One of these sets (set 13) has been studied in detail and appears to be truly monozygous; reciprocal skin grafts were accepted by both twins. However, evidence from buccal smears and chromosomal analysis suggests that one of the two twins is an $\mathrm{XX} / \mathrm{XO}$ mosaic, ${ }^{8}$ which could adequately account for the discrepancy in MET results. It has not been possible to study the other set of twins (set 15) to this extent. Mosaicism could be involved, they could represent an unusual set of dizygous twins who happen to resemble each other closely, or they could be monozygous twins whose values in the MET differ for reasons we do not understand.

Under the hypothesis of genetic control of $\mathrm{X}$-inactivation the expectation for the degree of agreement in MET results in dizygous twins heterozygous for G-6-PD deficiency varies according to the genetic hypothesis for control. If genetic control is resident solely in the $\mathrm{X}$-chromosome, two classes of dizygous twins should result; those that agree as closely in MET results as monozygous twins because of their sharing the same set of X-chromosomes (in the absence of crossing over), and those that disagree because they do not. The same expectation would result from control residing on a single autosome. The absence of a closely-agreeing class of dizygous twins is evidence against both of these hypotheses. Not excluded is a hypothesis based on multifactorial autosomal control; the expectation for the intraclass correlation here would be somewhere below 0.50 for dizygous twins, the amount below 0.50 depending upon the amount of nongenetic variation in the system. The actual intraclass correlation of 0.34 is at least consistent with this hypothesis.

Precedent perhaps exists for nonrandom $X$-inactivation. In cases where abnormal $\mathrm{X}$-chromosomes have been studied using tritiated thymidine labeling techniques, the abnormal X-chromosome has been shown to be the late labeling (and sex chromatin forming) chromosome (Giannelli, 1963; Muldal et al., 1963; Grumbach et al., 1963; Miller et al., 1963; Atkins and Santesson, 1964; London et al., 1964; Rowley et al., 1964). This evidence supports the concept that a specific X-chromosome may be preferentially inactivated in a cell in contrast to purely random $\mathrm{X}$-inactivation, although the data can also be explained by cell selection, with loss of the cells in which the abnormal $\mathrm{X}$-chromosome is functional. Our current working hypothesis based on the MET data in twins discussed above and preliminary findings on nontwin relatives is that X-chromosome-inactivation is inherited. However, in the following paragraphs, we wish to consider other possible explanations for the data, most of which cannot be excluded at this time.

One such explanation is somatic cell selection after random $X$-inactivation. This hypothesis suggests that the two types of erythrocyte precursors (one with the maternal and one with the paternal $\mathrm{X}$-chromosome active) compete against each other and reach an equilibrium percentage in the bone marrow. The internal milieu of identical twins being closely comparable, the equilibrium percentage reached in this type of twin might be close to that of the co-twin. This explanation for the data would appear to be supported, in part, by the in vitro work of Gartler and Linder (1964). These investigators have shown that after long-term culture, one type of cell (that bearing the

8 Chromosomal studies were performed by Dr. Margery S. Shaw, Department of Human Genetics, University of Michigan. Further details on this set of twins will be published separately (Gall, Shaw, Dern, and Brewer). 
nondeficient G-6-PD allele) overgrows the other in cell cultures derived from females heterozygous for G-6-PD deficiency. In these experiments, one cell type completely overgrows the other, rather than an equilibrium being reached; however, the absence of the normal controls which might be operative in vivo could possibly explain a difference in in vitro results.

Another possible explanation for the MET data, beside inheritance of X-inactivation, is an inherited difference in generation time of the two types of cells. The objection to this is that the production rates would have to be rather markedly different (threefold) for the two types of cells to produce 75-25 heterozygotes, such as in identical sets 9 and 16. It must be remembered that the X-chromosomes determining these markedly different production rates would be present singly in males, and it is questionable that such markedly disparate production rates would be tolerated.

A related explanation, which also would not require inheritance of $X$-inactivation is easier to exclude. This hypothesis would hold that the equilibrium reached in heterozygotes is based on an inherited differential survival rate of the two types of erythrocytes. From studies of red-cell survival curves in males we can be certain that survival times of red cells do not show the requisite variability (Brewer, Tarlov, and Powell, unpublished).

There are two additional explanations for the very close agreement in MET results in 6 of the 8 sets of identical twins, which have to do with the fact that the studies were conducted on twins. It is well known that most identical twins partially share placental circulations and this could result in complete mixing of erythrocyte precursors after X-inactivation occurs, with the subsequent development of exactly equal proportions of the two types of cells. The lack of perfect agreement in a small proportion of identical sets could be attributed to a lack of sufficient shared placental circulation for even mixing to occur (if cleavage for twin formation occurs sufficiently early, two placentas, without extensive shared circulations, may be formed-Siemens, 1925; Essen-Moller, 1941). The other explanation is the possibility that X-inactivation occurs prior to cleavage for twin formation, and that cell mixing is complete at the time of cleavage. However, the scanty data on time of formation of sex chromatin in the human embryo (12-19 days, Park, 1957) do not support such an early X-inactivation. (Cleavage for monozygous twin formation normally occurs prior to the seventh day post-fertilization, Coulton et al., 1947.) Although these latter conditions could possibly be playing roles in the observations in identical twins, they could not be the explanation for our preliminary findings of significant correlations in MET cell counts in nontwin siblings heterozygous for G-6-PD deficiency (Gall and Brewer, unpublished).

We would like to stress the idea that, irrespective of the cause of the extremely close agreement between most monozygous twins in proportion of maternally-derived versus paternally-derived $\mathrm{X}$-chromosomes active, the phenomenon is probably important biologically and should be further elucidated. If the agreement is primarily a result of cell selection, then the MET employed on heterozygotes for G-6-PD deficiency may be useful for measuring and studying this selection; if the agreement is a result of cell mixing in monozygous twins, this system could be useful for studying this phenomenon; and if the agreement results from inheritance of X-chromosomal inactivation, the system should be useful to further quantitate and characterize this inheritance. 


\section{Discussion of G-6-PD Assay Results}

Whether the G-6-PD assay results are considered in terms of the raw data or the relative activity (Table I), analysis of variance on heterozygous twins (Table II) indicates a significant genetic influence in determining enzyme activity. Theoretically, the genetic influence detected with the raw data could be due to genetic control of $\mathrm{X}$-inactivation, to genetically determined quantitative differences in enzyme activity (e.g., isoalleles), or to both. Calculation of the relative activity is an effort to factor out variation due to $\mathrm{X}$-inactivation. The intrapair differences for the relative activity (Table I) are numerically greater for both monozygous and dizygous twins than the original intrapair differences of the raw data. However, the relative activity values are also inflated (or numerically greater) than the raw values and, in fact, the difference between pairs is reduced when considered in relative terms. The ratios of the mean intrapair differences to the mean values shown at the bottom of the monozygous and dizygous sections of Table I demonstrate this. In any event, the significance of the $F$ ratio calculated on the relative activity data (Tables I and II) indicates that there are significant genetic influences on G-6-PD activity other than X-inactivation in the Negro population. This may be due to a series of quantitative isoalleles at the G-6-PD locus as suggested by Davidson et al. (1964) based on data from the Sardinian population.

The significant $F$ ratio with the G-6-PD data of both female and male nondeficient twins is a further indication of genetic control of enzyme activity. Once again, this may be due to a series of quantitative isoalleles or to other unknown genetic factors. In the case of the nondeficient-female data, we are of course measuring the influence of X-inactivation in addition to other factors, because we cannot factor out the effect of X-inactivation in the absence of heterozygosity for the deficiency. In the males, $\mathrm{X}$-inactivation could not be a factor, yet the $F$ ratio remains highly significant. We have also calculated from the data in Table IV, the $F$ ratio of the within-twin mean squares of the female twins to the within-twin mean squares of the male twins. This ratio for monozygous twins is 2.37 and for dizygous twins 3.45 . The latter is significant at the one-percent level. This suggests that there is a significantly greater variability between female twins, at least in the case of dizygous twins, than between their male counterparts. This greater variability could, of course, be due to sex-related phenomena, but it is also possible that it is at least partially due to increased variation introduced by $\mathrm{X}$-chromosome inactivation in the female.

\section{APPENDIX}

\section{Correction of G-6-PD Activity in G-6-PD Deficient Heterozygotes}

This correction assumes X-chromosomal inactivation and that the deficient cells in the heterozygous female have an expression of the enzyme deficiency similar to that of the cells of the deficient male and homozygous deficient female. The correction is based on the observation that the G-6-PDdeficient homozygous male Negro and homozygous female Negro have, on the average, $16 \%$ staining cells (cells with significant G-6-PD activity) in the MET and G-6-PD activity equivalent to reduction of $28 \mu$ moles of TPN per gram of hemoglobin per hour $(23 \mathrm{C})$. The percent of genetically unaffected (nondeficient) cells in heterozygotes is determined by applying the following formula:

$$
Y=X+0.16(100-X)
$$


where $Y$ is the percent of stained cells (cells with appreciable G-6-PD activity) in the MET, $X$ is the percent of genetically unaffected (nondeficient) cells, and $0.16(100-X)$ is the percent of enzymedeficient cells in a heterozygote staining in the MET (the relatively young deficient cells). After solving for $X$, the percent of genetically affected (deficient) cells is easily determined by subtracting $X$ from 100 .

The G-6-PD activity of nondeficient cells is determined as follows:

G-6-PD ACTIVITY OF GENETICALLY UNAFFECTED (NONDEFICIENT) CELLS

$$
=\text { RAW G-6-PD ACTIVITY }-\frac{\text { PERCENT DEFICIENT CELLS }}{100} \times 28
$$

where 28 is the mean G-6-PD activity in deficient males and homozygous deficient females $(100 \%$ deficient cells).

The "relative activity" (see text) of the genetically unaffected (nondeficient) cell population is determined by

$$
\text { RELATIVE ACTIVITY }=\frac{\text { ACTIVITY of GENETICALLY UNAFFeCTED (NONDEFICIENT) CELLS }}{\text { PERCENT GENETICALLY UNAFFECTED (NONDEFICIENT) CELLS }} \times 100
$$

\section{REFERENCES}

Atkins, L., and Santesson, B. (1964). The pattern of DNA synthesis in the chromosomes of human cells containing an isochromosome for the long arm of an X-chromosome. Hereditas 51: 67.

Barr, M. L., and Bertram, E. G. (1949). A morphological distinction between neurones of the male and female, and the behaviour of the nucleolar satellite during accelerated nucleoprotein synthesis. Nature 163: 676.

Beutler, E., Yeh, M., and Fairbanks, V. F. (1962). The normal human female as a mosaic of Xchromosome activity: Studies using the gene for G-6-PD deficiency as a marker. Proc. Nat. Acad. Sci. (U.S.) 48: 9.

Beutler, E., and Baluda, M. C. (1964). The separation of glucose-6-phosphate dehydrogenase deficient erythrocytes from the blood of heterozygotes for glucose-6-phosphate dehydrogenase deficiency. Lancet i: 189

Boyer, S. H., Porter, I. H., and Weilbacher, R. G. (1962). Electrophoretic heterogeneity of glucose-6phosphate dehydrogenase and its relationship to enzyme deficiency in man. Proc. Nat, Acad. Sci. (U.S.) 48: 1868.

Brewer, G. J., Tarlov, A. R., and Alving, A. S. (1960). Methemoglobin reduction test: A new simple in vitro test for identifying primaquine sensitivity. Bull. World Health Organ. 22: 633.

Brewer, G. J., Gall, J. C., Honeyman, M. S., Gershowitz, H., Dern, R. J., and Hames, C. G. (1965). Inheritance of quantitative expression of G-6-PD deficiency in heterozygous Negro females-A twin study. Clin. Res. 13: 265 (abst.).

Carson, P. E., Flanagan, C. L., Ickes, L. E., and Alving, A. S. (1965). Enzymatic deficiency in primaquine-sensitive erythrocytes. Science 124: 484.

Childs, B., and Zinkham, W. H. (1959). The genetics of primaquine sensitivity of the erythrocytes. Ciba Foundation Symposium on Biochemistry of Human Genetics. Little, Brown, and Company, Boston, pp. 76-88.

Coulton, D., Hertig, A., and Long, W. N. (1947). Monoamniotic twins. Am. J. Obst. and Gynec. 54: 119.

Davidson, R. G., Nitkowsky, H. M., and Childs, B. (1963). Demonstration of two populations of cells in the human female heterozygous for glucose-6-phosphate dehydrogenase variant. Proc. Nat. Acad. Sci. (U.S.) 50: 481.

Davidson, R. G., Childs, B., and Siniscalco, M. (1964). Genetic variations in the quantitative control of erythrocyte glucose-6-phosphate dehydrogenase activity. Ann. Human Genet. 28: 61.

Essen-Moller, E. (1941). Empirische ahnlichkeitsdiagnose bei zwillingen. Hereditas 27: 1.

Gall, J. C., Brewer, G. J., and Dern, R. J. (1965). Studies of glucose-6-phosphate dehydrogenase activity of individual erythrocytes: The methemoglobin-elution test for identification of females heterozygous for G-6-PD deficiency. Am. J. Human Genet. 17: 359.

Gall, J. C., and Brewer, G. J. (1966). Studies of individual RBC in G-6-PD deficient heterozygotes and hemizygotes. Clin. Res. 14: 309 (abst.).

Gartler, S. M., and Linder, D. (1964). Selection in mammalian mosaic cell populations. Cold Spring Harbour Symp. Quant. Biol. Vol. 29. 
Giannelli, F. (1963). The pattern of X-chromosome deoxyribonucleic acid synthesis in two women with abnormal sex chromosome complements. Lancet i: 863.

Grumbach, M. M., Morishima, A., and Taylor, J. H. (1963). Human sex chromosome abnormalities in relation to DNA replication and heterochromatinization. Proc. Nat. Acad. Sci. (U.S.) $49: 581$.

Kirkman, H. N., and Hendrickson, E. M. (1963). Sex-linked electrophoretic difference in glucose-6phosphate dehydrogenase. Am. J. Human Genet. 15: 241.

London, D. R., Kemp, N. H., Ellis, J. R., and Mittwoch, U. (1964). Turner's syndrome with secondary amenorrhoea and sex chromosome mosaicism. Acta Endocrinol. 46: 364.

Lyon, M. F. (1961). Gene action in the X-chromosome of the mouse (Mus musculus L.). Nature 190: 372 .

Marks, P. A., Johnson, A. B., and Hirschberg, E. (1958). Effect of age on the enzyme activity in erythrocytes. Proc. Nat. Acad. Sci. (U.S.) 44: 529.

Miller, O. J., Mukherjee, B. B., Bader, S., and Christakos, A. C. (1963). Autoradiographic studies of $\mathrm{X}$-chromosome duplication in an XO/X-isochromosome mosaic human female. Nature 200: 918.

Muldal, S., Gilbert, C. W., Lajtha, L. G., Lindsten, J., Rowley, J., and Fraccaro, M. (1963). Tritiated thymidine incorporation in an isochromosome for the long arm of the X-chromosome in man. Lancet i: 861 .

Ohno, S., Kaplan, W. D., and Kinosita, R. (1959). On the sex chromatin of Gallus Domesticus. Exp. Cell Res. 19: 180.

Park, W. W. (1957). The occurrence of sex chromatin in early human and macaque embryos. J. Anat. 91: 369 .

Porter, I. H., Boyer, S. H., Schulze, J., and McKusick, V. (1961). Genetic control of glucose-6phosphate dehydrogenase production. In Proceedings of the Second International Conference of Human Genetics, Rome, 1961, Vol. 1. Instituto G. Mendel, Rome, pp. 618-621.

Siemens, H. W. (1925). Die diagnose der eineiigkeit. Arch. Gynak. 126: 623.

Rowley, J., Muldal, S., Lindsten, J., and Gilbert, C. W. (1964). $\mathrm{H}^{3}$-thymidine uptake by a ring X-chromosome in a human female. Proc. Nat. Acad. Sci. (U.S.) 51: 779.

Zinkham, W. E., and Lenhard, R. E. (1959). Metabolic abnormalities of erythrocytes from patients with congenital nonspherocytic hemolytic anemia. J. Pediat. 55: 319. 